\title{
Returns of merger and acquisition activities in the gaming industry
}

Hyun Kyung Chatfield

University of Nevada Las Vegas

Robert E. Chatfield

University of Nevada Las Vegas

Yen-Soon Kim

University of Nevada Las Vegas

\section{Recommended Citation}

Chatfield, H. K., Chatfield, R. E., \& Kim, Y. S. (2018). Returns of merger and acquisition activities in the gaming industry. International Interdisciplinary Business-Economics Advancement Journal, 3(1), 40-56.

\section{Revisions}

Submission date: Nov. 11, 2017

1st Revision: Feb. 5, 2018

Acceptance: Feb. 23, 2018 


\title{
Returns of Merger and Acquisition Activities in the Gaming Industry
}

\author{
Hyun Kyung Chatfield ${ }^{1}$, Robert E. Chatfield ${ }^{2}$, \\ and Yen-Soon $\mathrm{Kim}^{3}$
}

\author{
William F. Harrah College of Hospitality \\ University of Nevada Las Vegas, United States \\ ${ }^{1}$ grace.chatfield@unlv.edu \\ ${ }^{3}$ yen-soon.kim@unlv.edu \\ Lee College of Business \\ University of Nevada, Las Vegas, United States \\ ${ }^{2}$ robert.chatfield@unlv.edu
}

\begin{abstract}
The gaming industry experienced numerous merger and acquisition (M\&A) activities in the 1990s. This study examines the cumulative abnormal returns (CARs) for gaming target and bidding firms around the announcement of mergers and acquisitions (M\&As) from 1985 to 2004. The results showed that both targets and bidders had significant positive returns. The study finds that gaming targets enjoy significant positive returns consistent with the literature. Gaming industry bidders earn significant, positive returns. The literature on bidder returns shows mixed results; some were positive, some were negative but many are not significantly different from zero. The positive bidder returns in the gaming industry found here are possibly caused by the high entry barriers to the gaming industry such as acquiring gaming licenses, familiarity of gaming regulations, and experience. It is generally much more difficult for a non-gaming bidder than a gaming bidder to acquire gaming industry targets. As a result, there is usually much less competition in gaming industry M\&As than for other industries. This is likely a major cause of the higher returns for gaming bidders than found for bidders in most other industries.
\end{abstract}

Keywords: merger and acquisitions, gaming industry, cumulative abnormal return

\section{Introduction}

Mergers and acquisitions (M\&A) play a significant role in the growth of business and allow firms to expand more quickly than they could naturally. Growing firms are generally healthy firms and will typically attract more customers, higher quality employees and investors. Through successful mergers, firms can take advantage of economies of scale, reduction in average costs, increased revenues, and create more growth opportunities than otherwise.

M\&A decisions should be made based upon the maximization of shareholder wealth. A company should invest in projects that generate a positive net present value including M\&A investments. Survey evidence shows that CFOs believe achieving operating synergies and a positive net 
present value investment are the most significant motivations for an M\&A (Mukherjee, Kiymaz, \& Baker, 2004).

Acquisitions may be by tender offer or a friendly, negotiated merger. A tender offer is a type of takeover where a bidder uses a public offer or directly offers to purchase shares from target shareholders. On the other hand, friendly mergers are negotiated and accepted by shareholders and management of the target firms. Tender offers tend to be hostile and mergers tend to be friendly deals.

Three different methodologies for assessing merger success have been nicely explained by Canina, Kim, and Ma (2010) as follows: “... based on stock prices around the public announcement of the M\&A, stock prices after merger completion, and operational performance after merger completion" (p. 83). The first method, based on stock returns around the announcement date, is the main method used in the finance literature (Canina et al., 2010). Despite the first method being the main method used in the finance literature, to the best of our knowledge this method has not been used to investigate merger success in the gaming industry in any published study. This is the focus of our study. We do examine announcement period abnormal returns to measure merger success in the gaming industry.

There have been many gaming M\&As in Las Vegas over the last several years. In September 2016, Boyd Gaming acquired Aliante Station for $\$ 380$ million (Boyd Completes, 2016) and earlier in the fall, it bought the Eastside Cannery on Boulder Highway and the Cannery casino in North Las Vegas (Moore, 2017; Station Casinos, 2016). In addition, in fall of 2016, Station Casinos LLC completed its purchase of the Palms, west of the Las Vegas Strip, for \$312.5 million (Boyd Completes, 2016; Moore, 2017). The Palms' clientele includes both locals and tourists. And in May 2017, SLS announced it had agreed to be purchased by Alex Meruelo and Meruelo Group, owners of the Grand Sierra Resort in Reno (Moore, 2017).

Alex Bumazhny, a gaming industry analyst and senior director for Fitch Ratings said, "consolidation in gaming, broadly, has been happening over the past 10-15 years in a bigger sort of way in the regional and Las Vegas Strip side, and in the last years, we're seeing it more rapidly on the local's side as well" (Moore, 2017, para. 4). According to John DeCree, a gaming analyst with Union Gaming, gaming mergers have been common due to the economies of scale resulting from consolidation. DeCree said: "We're seeing a continued consolidation across all regional gaming. That's just driven by the efficiencies of scale and synergies it produces. The more properties you can own and greater scales you have, the better and more efficient it is" (Moore, 2017, para. 9).

A number of studies have considered returns to M\&A activity. They not only show returns vary over time, but also that the combined target and bidder response is uncertain. Bidder returns have a slight tendency to decline for the period between the 1960s and 1990s (Chew \& Gillan, 2009). It appears that bidder returns were higher (more positive) in the 1960s and 1970s than in the 1980s and 1990s (Chew \& Gillan, 2009).

M\&A targets showed significant gains from takeovers in the 1980's (Weston, Siu, \& Johnson, 2001). In recent years, the government has increased merger regulation along with the 
development of sophisticated defense tactics by target firms. As a result, target firms' returns increased and the bidding firms' returns decreased over this same time (Weston et al., 2001).

The purpose of this study is to examine the returns surrounding merger and acquisition activities for both bidders and target firms in the gaming industry. Past M\&A studies have been extensive considering the overall market as well as individual industries such as banking, utility, hospitality, lodging and restaurants (Adams, Johnson, \& Pilloff, 2009; Altunbas, Gardener, Molyneux, \& Moore, 2001; Altunbas \& Marquez, 2008; Anderson, 1999; Berger, Bonime, Goldberg, \& White, 2004; Besanko, D’Souza, \& Thiagarajan, 2001; Canina, 2001; Chatfield, Chatfield, \& Dalbor, 2012; Chatfield, Dalbor, \& Ramdeen, 2011; Chew \& Gillan, 2009; CyboOttone \& Murgia, 2000; DeLong, 2001; Fecht \& Grüner, 2008; Focarelli, Panetta, \& Salleo, 2002; Houston, James, \& Reingaert, 2001; Jaber, 2004; Kwan, \& Eisenbeis, 1999; Rhoades, 1992; Rhoades, 1998; Zhang, 1995). Past merger waves are usually industry specific which would seem to indicate that M\&A performance is likely to vary from industry to industry. The gaming industry is clearly unique with many differentiating characteristics from most other industries. Differences include significant taxes targeted specifically to gaming properties, regulatory restrictions on who is allowed to own and operate a gaming property, severe geographic restrictions on where gaming properties are allowed to operate, and then strong regulation on the overall operations of a gaming property. As a result of these differences between the gaming industry and other industries there is no reason to expect the results of M\&A activity to be the same.

During the past 15 years or so, numerous mergers and acquisitions occurred in the gaming industry. In June of 2005, Harrah's Entertainment obtained Nevada regulators' permission to complete its $\$ 9.4$ billion merger with Caesars Entertainment, once the largest gaming company. After the merger, Harrah's became the world's largest gaming company including 56 casinos and almost 42,000 hotel rooms in 13 states and four other nations. In April 2005, MGM Mirage bought out Mandalay Resort Group, previously the fourth largest casino company in Las Vegas, for $\$ 7.9$ billion. At the time it was the largest merger in history in this industry. As of 2005, twenty-five percent of all commercial gaming revenues in the United States were generated in Las Vegas. These megamergers have certainly changed the competitive environment in the U.S. gaming industry and especially the competitive environment in the Las Vegas segment of the gaming industry.

The gaming industry is highly regulated and thus has significant entry barriers. Between 1993 and 1998, the gaming industry experienced significant revenue growth, heavy capital spending, declining profitability, and the increased use of debt financing (Rogers, 2005). Rogers (2005) claims casino gaming industry stock prices were very weak during 1994-1998. During this time, gaming industry stock price performance was ranked 120th of 122 industry categories in the Compustat Research Insight database (as cited in Rogers, 2005).

A merger wave swept through the gaming industry during the last few decades. Despite this merger wave in the gaming industry, there is very little published research on M\&A activity in the gaming industry. This study will investigate cumulative abnormal returns (gains) around public announcement of M\&As for both bidder and target firms in the gaming industry. There is no previously published gaming industry study using this methodology, the finance literature's most common method of assessing M\&A success; an event study methodology. 


\section{Literature Review}

The historical record shows that returns of merger participants fluctuate over time. Despite the fluctuating record, one common theme is for target returns to be positive and higher than bidder returns. On the other hand, the returns to bidders have been quite mixed, some are positive and some are negative. A number of variables have the potential to influence returns for both bidder and target companies. These include different industry type, the nature of the acquisition, and whether the target firm is private or public. This section presents theoretical developments and empirical findings of previous M\&A studies.

\section{Target Returns - Empirical Results}

The M\&A literature overwhelmingly shows target firms gain positive and higher returns than bidders. Twenty-five M\&A studies between 1978 and 2003 report positive target returns from $7.45 \%$ to $45.6 \%$ for short term windows (Bruner, 2004). One study of 399 large U.S. acquisitions from the 1970s to the 1980s found target shareholders average a $28 \%$ gain after the merger announcement (Franks, Harris, \& Titman, 1991). Another study of M\&As from the mid 1970's to the early 1990's found abnormal returns averaging 35\% to 40\% (Schwert, 1996). Further support for these conclusions comes from the empirical research of You, Caves, Smith, and Henry (1986). They examined 133 mergers between 1975 and 1984 using a frequency distribution analysis. Their results were a wide range of returns for target shareholders with $82 \%$ having positive excess returns, $20 \%$ with positive excess returns above $40 \%$ and an overall $20 \%$ average excess return.

Since the late 1960's merger regulation has intensified and potential target firms have been developing defensive tactics. Weston et al. (2001) concludes that targets' returns have increased and bidders' returns have decreased as a result.

\section{Bidder Returns - Empirical Results}

The results for bidder returns in the literature are mixed. Returns to bidders are typically lower than for targets and are often not significantly different than zero. An assortment of positive returns and negative returns are found depending upon the study. The literature shows bidder returns have a slight tendency to decline for the period between the 1960s and 1990s. Bidder returns were higher (more positive) in the 1960s and 1970s than in the 1980s and 1990s (Chew \& Gillan, 2009). The technology and banking industries were an exception where returns to bidders were higher in the 1990s (Chew \& Gillan, 2009).

A study by Bradley, Desai, and Kim (1988) of bidder returns between the 1960's and the 1980's argues that the rapid development of new financing techniques, new defensive strategies, and a more relaxed antitrust attitude towards horizontal mergers encouraged more competing bids in the 1980's than in the previous two decades. Their results support this argument, as bidder returns were significantly lower in the 1980's than in the previous two decades. The average announcement returns to bidders were $4.1 \%$ in the 1963 to 1968 period but $-2.9 \%$ in the 1981 to 1984 period (Bradley et al., 1988). Additionally, bidders' returns dramatically declined from 1997 to 2001 (Moeller, Schlingemann, \& Stulz, 2003). 
A study of 399 large U.S. acquisitions from the 1970s to the 1980s found that following the merger announcement, bidder returns are close to zero (Franks et al., 1991). The stock price of bidder companies decreased by one percent but was not statistically significant. A frequency distribution analysis by You et al. (1986) had similar results. Bidder excess returns from their sample of M\&As between 1975 and 1984 were a negative one percent. The actual range of bidder returns was very wide with about $47 \%$ of bidder returns positive and $53 \%$ negative. Schwert's (1996) study concluded that bidders, on average, did not make gains from the mid 1970 's to the mid 1990's.

Some large corporations performed very well with takeovers in the 1990's including some in the high-tech sector. One notable example is Cisco Systems. They generated high returns from several M\&As during this time period. A number of Internet firms were able to enhance growth and returns with acquisitions during this time period as well.

Mergers were still risky for bidders from the 1960s to 1990s with many failing to generate gains and often generating losses. Negative returns were found with a slight majority of bidding firms during this time, but there were still a significant number of bidder firms, even though a minority generated positive returns. The awareness that some bidding firms were generating significant positive returns probably helped to motivate bidders to continue acquisitions even though the average return from M\&A activity was negative.

\section{Bidder Returns for Private Versus Public Targets}

There are evidence bidders do better when targets are less liquid (private firms) and worse when targets are more liquid (public firms). Fuller, Netter, and Stegemoller (2002) found bidder returns of public targets to be significantly negative and bidder returns of private targets to be significantly positive. A number of studies (Betton, Eckbo, \& Thorburn, 2008; Capron \& Shen, 2007; Chang, 1998; Hansen \& Lott, 1996) also show that acquirers of private firms experience higher returns than acquirers of public firms. This difference in returns to acquirers of private versus public targets may be explained by the illiquidity of private targets as well as information asymmetry between private targets and acquirers (Canina et al., 2010; Chang, 1998; Fuller et al., 2002).

\section{The Impact of Industry on $M \& A s$}

M\&A returns have been found to vary across industries. This is not surprising given the varying characteristics and environments of different industries. Many M\&A studies have focused on the banking and utility industries because of their distinct regulatory and industry characteristics. The gaming industry differs in many respects from other industries such as utility, manufacturing, banking, etc. Differences include significant taxes targeted specifically to gaming properties, regulatory restrictions on who is allowed to own and operate a gaming property, and severe geographic restrictions. Although the gaming, utility and banking industry all have strong government regulation, the nature of the regulation is very different between the three industries. Yet studies of M\&A performance in the gaming industry are very limited. There is a related study in the lodging industry that touched upon gaming (Kim, 2001). Kim (2001) found targets of non-casino hotels averaged 5.2\% excess returns and targets of casino hotels averaged excess returns of $16.1 \%$. Arik and Kutan (2015) found from a sample of 1,648 European M\&As from 
1997 to 2013 target firm's abnormal return were 5.17 percent. They also found the target firm's stock return is lower in heavily regulated industries and if the acquiring entity is a private equity fund. However, they didn't study bidding firm's abnormal return.

\section{Merger Waves \& the Hospitality Industry}

Although, studies of merger waves reveal different characteristics, they also seem to share some similarities. Merger waves occurred in a period of low or falling interest rates, a rising stock market, and an expanding economy. During a period of increasing real interest rates or increasing cost of capital, mergers and acquisitions seem to slow down (Bruner, 2004).

Very little empirical research on the impact of M\&As in the gaming industry has been performed. The hospitality industry in general has received some attention (Oak \& Andrew, 2003; Oak, Andrew, \& Bryant, 2008; Sheel \& Nagpal, 2000; Yang, Qu, \& Kim, 2009; Yang, Kim, \& Qu, 2010). Hsu and Jang (2007) found that bidder's in the hotel industry experienced no significant returns around the acquisition announcement and had negative returns in the longterm. Chatfield et al. (2012) studied abnormal returns for a sample of 282 hospitality firms and found bidder's abnormal return is more likely to be higher if payment is made with cash. This supports the asymmetric information and signaling theory arguments for bidding firms earning positive abnormal returns for cash offers, but stock offers having returns not significantly different than zero. However, Yang et al. (2009) found that there are no significant different abnormal returns for hospitality acquirers based on method of payment. Dogru (2017) argued regardless of the method of payment, financially constrained bidder firms earned significantly higher positive returns than unconstrained firms. They also found franchising and hotel-real estate investment trust (REIT) bidders earn negative returns from acquisition.

There is one recent study on M\&A activity in the restaurant industry (Chatfield et al., 2011) and a number of studies regarding the lodging industry (Bloom, 2010; Canina, 2001; Canina et al., 2010; Hsu \& Jang, 2007; Ma, Zhang, \& Chowdhury, 2011). Canina et al., (2010) is an excellent survey of the literature on M\&A research in general.

\section{Hypotheses}

Based on the previous studies, several hypotheses are developed. We will consider the returns to all gaming targets, and the returns to all gaming bidders. However, we expect the returns to gaming bidders to be different based upon whether targets are gaming firms or not. This is due to gaming regulations restricting ownership of gaming companies and thus reducing competition for the acquisition of gaming targets. Thus, we examine the returns to bidders of gaming targets and separately consider the returns to bidders of nongaming targets. Finally, we consider bidder returns of public gaming targets. There is strong evidence that bidders of private targets perform much better than bidders of public targets. Thus, we consider whether the impact of gaming regulation is sufficiently strong as to cause significant positive returns to bidders of gaming targets even when the gaming targets are public. This will shed additional light on the impact of gaming regulation on the returns to acquisitions of gaming targets. 


\section{Target Returns}

The literature shows that target returns from M\&A activity are usually significantly positive and we expect the same from the M\&As of gaming targets. Since target returns are generally positive, a one-tail test is performed.

Hypothesis 1: Mean cumulative abnormal return (CAR) to target firms associated with M\&A activity in the gaming industry is less than or equal to zero.

- H1: Mean of gaming target $\mathrm{CAR} \leq 0$

\section{Bidder Returns}

The literature has mixed results regarding bidder returns from M\&A activity and the only consistently significant positive returns to bidders are with M\&As with unique characteristics such as private targets. Although the data used here includes some M\&As with these unique characteristics, the only unifying characteristic defining all the bidders is they are all gaming companies. Thus, due to the mixed results of bidder returns from the literature, a two-tail test is performed.

Hypothesis 2: Mean cumulative abnormal return (CAR) to bidder firms associated with M\&A activity in the gaming industry is equal to zero.

- $\mathrm{H} 2$ : Mean of gaming bidder $\mathrm{CAR}=0$

\section{Bidder Returns When Target Is Gaming}

We argue that bidder returns for gaming targets are more likely to be positive than other bidder returns due to gaming regulation that reduces bidder competition. Thus, we examine bidder returns for M\&As of gaming targets versus bidder returns for non-gaming targets. Because we expect bidder returns for gaming targets to be positive, a one-tailed test is performed here. To be clear here, all the bidders are gaming firms, whereas some of the targets are gaming firms and some are not.

Hypothesis 3: Mean cumulative abnormal return (CAR) to bidder firms when acquiring gaming targets is less than or equal to zero.

- H3: Mean of bidder firms' CAR when target is gaming $\leq 0$

Hypothesis 4: Mean cumulative abnormal return (CAR) to bidder firms when acquiring nongaming targets is less than or equal to zero.

- H4: Mean of bidder firms CAR when target is non-gaming $\leq 0$

\section{Bidder Returns When Target Is Gaming and Public}

Generally, the literature shows that bidder returns from M\&As of private targets is significantly positive and bidder returns from M\&As of public targets is not significantly positive. We examine bidder returns for M\&As of public, gaming targets with the expectation that these 
returns will still be positive despite previous findings of insignificant bidder returns from public targets. This is due to the impact of gaming regulation causing bidder returns to be positive. As a result, a one-tailed test is performed.

Hypothesis 5: Mean cumulative abnormal return (CAR) to bidder firms when acquiring public, gaming targets is less than or equal to zero.

- H5: Mean of bidder firms CAR when target is public and gaming $\leq 0$

\section{Methodology}

\section{Sample and Data}

This section describes the data collection for a study of mergers and acquisitions (M\&A) activities in the gaming industry between 1985 and 2004. Mergers and acquisitions data are collected from Security Data Corporation (SDC). Firms are classified according to the acquirer's ultimate parent Standard Industry Code (SIC, 7993 and 7999, gaming and casinos) from Security Data Corporation. Stock price information was collected from the Center for Research in Security Prices (CRSP) file. Only stocks traded on the New York Stock Exchange (NYSE), American Stock Exchange (AMEX), and Nasdaq stock markets are included in the sample. If the same bidder is involved in several M\&As, each transaction is counted as a separate M\&A.

The final sample included 79 M\&A cases. Cumulative abnormal returns were available for all 79 gaming bidders but were only available for 9 targets. The smaller number of targets included in the study was due to the lack of stock price information. This lack of stock price information was mainly caused by the private status of most targets. Gaming bidders were identified using the standard industry code (SIC) for gaming (7993 and 7999, gaming and casinos). Among these 79 M\&As, the sample of bidding firms is very different than the sample of target firms. All the bidding firms are public corporations, since our data sources do not include private bidding firms. Also, all the bidding firms are gaming industry by design. On the other hand, the target firms include public and private companies. We have restricted this study to include only bidders acquiring public or private targets. All other bidders, such as those acquiring joint ventures and subsidiaries, were excluded from this study to avoid possible biases. So only bidders acquiring public or private targets, whether in the gaming industry or not, are included in this study.

The criteria for a sample of target firms to be considered for analysis of target returns are similar to bidders. Targets must be public companies in the gaming industry and be acquired by bidders in the hospitality (gaming, restaurant and hotel industry). We do consider some bidders acquiring private targets or targets outside the gaming industry. However, only the returns from public bidders in the gaming industry and the returns from public targets in the gaming industry are included in the statistical analysis and hypotheses testing.

Due to the restriction of CAR calculation criteria and the availability of bidders' stock price information, the final sample includes a total of 79 gaming bidder CARs and 9 gaming target CARs. Table 1 breaks down our sample of gaming industry M\&As by year from 1985 to 2004 . M\&A activities were particularly high from 1993 to 1994, 1997, 1999, and 2001. 
Table 1. Sample of Gaming M\&As from 1985 to 2004

\begin{tabular}{cc}
\hline Year announced & Number of Gaming M\&As \\
\hline 1985 & - \\
1986 & - \\
1987 & - \\
1988 & 1 \\
1989 & 2 \\
1990 & 1 \\
1991 & 2 \\
1992 & - \\
1993 & 9 \\
1994 & 10 \\
1995 & 4 \\
1996 & 4 \\
1997 & 9 \\
1998 & 3 \\
1999 & 11 \\
2000 & 5 \\
2001 & 7 \\
2002 & 2 \\
2003 & 4 \\
2004 & 5 \\
Total & 79 \\
\hline
\end{tabular}

Source: Security Data Corporation.

These 79 M\&As cases were further examined by target's public status, nature of acquisition (tender offer vs. merger), and target industry (see Table 2). The top part of the Table 2 shows gaming bidders acquired $64(81 \%)$ private target firms and 15 (19\%) public target firms. Private firms do not have stock price information, so only public target firms' CAR was calculated. Nine target firm CARs were available in this study. Among those 9 gaming targets, 6 of them are acquired by gaming firms and 3 of them are acquired by hotel firms.

There are very few tender offers over the last 20 years in the gaming industry (see the second part of the Table 2). In the sample of 79 bidders, only 2 are tender offers, and 77 are mergers. A tender offer is a type of takeover where a bidder uses a public offer or directly offers to purchase shares from target shareholders. On the other hand, friendly mergers are negotiated and accepted by shareholders and management of the target firms. The literature review shows that tender offers tend to be hostile and mergers tend to be friendly deals. We found one hostile deal in our gaming industry sample between 1985 and 2004. Based upon the evidence in this study, the gaming M\&A market appears to be quite friendly during this time period and this is supported by Halibozek and Kovacich (2005). They believe low interest rates and recent economic growth make for a friendly M\&A environment.

The third part of the Table 2 shows the number of M\&A cases by targets' industry type. Gaming industry bidders acquired 22 gaming targets, 1 restaurant, 27 hotels and 29 non-hospitality targets.

Standard event study methodology (Brown \& Warner, 1985) is used to determine abnormal returns for the bidding firms. This methodology is commonly used in finance research and makes for easy comparison with other studies. Event studies are based upon residual analysis and 
examine the changes in shareholder wealth ensuing from the announcement of mergers and acquisitions.

Table 2. Descriptive Information for Bidding Firms

\begin{tabular}{lcc}
\hline & Bidder industry type (Gaming) & $\%$ \\
\hline Target public status $(N=79)$ & 64 & $81 \%$ \\
$\quad$ Private & 15 & $19 \%$ \\
Public & 79 & $100 \%$ \\
$\quad$ Total & 77 & $97 \%$ \\
Tender offer vs. merger $(N=79)$ & 2 & $3 \%$ \\
$\quad$ Merger & 79 & $100 \%$ \\
$\quad$ Tender offer & 22 & $28 \%$ \\
$\quad$ Total & 1 & $1 \%$ \\
Target industry type $(N=79)$ & 27 & $34 \%$ \\
$\quad$ Gaming target & 29 & $37 \%$ \\
$\quad$ Restaurant target & & \\
$\quad$ Hotel target & 79 & $100 \%$ \\
$\quad$ Non-hospitality target & & \\
$\quad$ Other industry, not gaming, restaurant or hotel industry) & \\
$\quad$ Total & & \\
\hline Note: Table 2 shows descriptive Information for the sample of 79 bidding firms from 1985 to 2004 by targets
\end{tabular}

The day that an event (merger and acquisition) announcement is made for a particular firm is considered day zero. Each firm will generally have a different announcement date. The days near the announcement date are considered the event period and this period is selected to obtain all stock price changes resulting from the event. A two-day event period is used including the day before the announcement and the day of the announcement $(-1,0)$. Although a number of other event periods have been used in previous studies, this two-day $(-1,0)$ event window is commonly used (Beitel, Schiereck, \& Wahrenburg, 2004; Chatfield et al., 2011; Goergen, \& Renneboog, 2003; Kohers, \& Kohers, 2001; Mitchell, \& Stafford, 2000; Mulherin, \& Boone, 2000). This assumes that all information effects from the announcement are captured in this twoday period.

The market model is estimated by running an ordinary least squares regression over an estimation period. The estimation period begins 240 days before the announcement and ends 61 days before the announcement. This estimation period should be a clean period.

The market model is:

$R_{i t}=\alpha_{i}+\beta_{i} R_{m t}+\varepsilon_{i t}$

where:

Rit $=$ the return for firm $\mathrm{i}$ on day $\mathrm{t}, \alpha \mathrm{i}=$ the mean return not explained by the market, $\beta \mathrm{i}=$ firm i's relationship with the market return (i.e., its risk factor),

$\mathrm{Rmt}=$ the return on the market on day $\mathrm{t}$, where the return on the CRSP equal-weighted stock index is used as a proxy for the market return.

$\varepsilon i t=$ the error term of the regression. 
The predicted return is the expected return if no event took place. The predicted return for firm " $i$ " on day " $t$ " in the event period is the return given by the market model using the estimates of $i$ and i obtained from the estimation period. Thus, the predicted return using the market model is:

$\hat{R}_{i t}=\hat{\alpha}_{i}+\hat{\beta}_{i} R_{m t}$

where Rmt is the return on the market index for the actual day in the event period.

Abnormal returns (AR), also referred to as excess returns or the residual, are estimated for each day in the event period for each firm. The event period in this study is a two-day period including the day before the M\&A announcement and the day of the M\&A announcement (-1, 0 ). Abnormal returns (AR) are calculated as the actual return for that day minus the predicted return from the estimation period. The AR represents the unpredicted portion of the return of each firm caused by the event:

$$
A R_{i t}=R_{i t}-\hat{R}_{i t}
$$

The average abnormal return $(\overline{A R})$ is the sum of the abnormal returns of all firms involved in mergers and acquisitions divided by $\mathrm{N}_{\mathrm{t}}$, the number of firms in the sample for the day $\mathrm{t}$.

$$
\overline{A R}_{t}=\frac{1}{N_{t}} \sum_{i=1}^{N_{t}} A R_{i t}
$$

The cumulative abnormal return (CAR) for each firm is calculated by accumulating the daily average abnormal returns (residual) over the 2-day event period. The CAR for a sample of firms represents the average total return of the event for this particular time period across all firms in the sample. This assumes that the 2-day event window captures all the information effects resulting from the event announcement.

The CAR is computed as:

$$
C A R=\sum_{t=t_{1}}^{t_{2}} \overline{A R_{t}}
$$

where $t_{1}$ is the first day (-1) in the event period and $t 2$ is the last day (0) in the event period.

To test whether a share price effect is statistically significant, a t-statistic is computed. The null hypothesis for the t-test is that the average CAR in the event window equals zero. Since target returns are generally positive, a one-tail test is performed. And due to the mixed results of the bidder returns, a two-tail test is performed. But for some bidder returns such as for bidders of gaming targets only, the expectation is for a positive return. For such bidder returns a one-tail test is performed. The one-sample $t$ test examines if the mean of the single variable (CAR) differs from a hypothesized zero value. That is, if there is no abnormal return from the announcement of the mergers and acquisitions (M\&A), the cumulative abnormal returns should be equal to zero. If there is an M\&A effect, cumulative abnormal returns should be significantly 
different from zero. For some of the hypotheses test, the sample size is less than 30 . In this case we will also perform the nonparametric, one-sample Wilcoxon signed rank test to consider if the returns are significantly different than zero.

\section{Findings}

\section{Testing Hypothesis: H1 Testing Gaming Target CARs}

H1: Mean of target CARs for gaming industry $\leq 0$

Table 3 summarizes t-test results for the hypotheses testing of target and bidder cumulative abnormal returns (CAR). The target CARs ranged from $0.20 \%$ to $42.19 \%$. The alternative hypothesis is that target return is greater than zero which is a one-tailed test. Since SPSS reports a two-tail test, the p-value is divided by two to calculate the probability value for a one tail test (SPSS Base 10.0, 1999).

Table 3: Cumulative Abnormal Return for Gaming Industry Target and Bidder from M\&As

\begin{tabular}{|c|c|c|c|c|c|c|c|c|}
\hline Hypotheses & Gaming & $N$ & $\begin{array}{c}\text { Mean } \\
(\%)\end{array}$ & $t$ statistic & $S D(\%)$ & $p$ & $\begin{array}{c}\text { Minimum } \\
(\%)\end{array}$ & $\begin{array}{c}\text { Maximum } \\
(\%)\end{array}$ \\
\hline $\mathrm{H} 1: \mu \leq 0$ & Targets & 9 & 11.91 & 2.621 & 13.63 & $\begin{array}{c}0.0155 * \\
(0.002 * *) \\
\end{array}$ & 0.20 & 42.19 \\
\hline $\mathrm{H} 2: \mu=0$ & Bidders & 79 & 3.18 & 2.772 & 10.19 & $0.007 * *$ & -12.66 & 55.91 \\
\hline
\end{tabular}

The mean CAR of gaming targets is $11.91 \%$ and is significant at the 5\% level. The hypothesis $\mathrm{H} 1$ is rejected. The sample size of gaming targets is small $(\mathrm{N}=9)$, thus an additional nonparametric test is performed. Nonparametric tests are distribution-free. The one-sample Wilcoxon signed rank test is an alternative for the one sample t-test and can be applied when distributional assumptions are questionable. The results of the non-parametric test are significant at the $1 \%$ level $(\mathrm{p}=0.002)$. The results are not surprising and are as expected given the rich literature showing M\&As targets usually earn significant positive returns.

\section{Testing Hypothesis: H2 Testing Gaming Bidder CARs}

H2: Mean of bidder CARs for gaming industry $=0$

Hypothesis $\mathrm{H} 2$ tests whether gaming bidder mean CARs are statistically different from zero. A total of 79 bidder CARs are available for this study. The bidder CARs range from $12.66 \%$ to $55.91 \%$. The average CAR for all bidders $(\mathrm{N}=79)$ is $3.18 \%, \mathrm{t}(78)=2.772, \mathrm{SD}=10.19 \%, \mathrm{p}<$ .01 .

Therefore, the gaming bidder mean CAR is significantly different from zero at the $1 \%$ level, and the hypothesis $\mathrm{H} 2$ is rejected. This is somewhat surprising as bidder returns from M\&A activity are not usually significantly positive except in specialized cases. This may be a specialized case that has not been previously investigated. Gaming regulation does restrict who can own a gaming company and as a result probably restricts competition for the acquisition of gaming companies. This should cause bidder returns from acquisitions of gaming companies to be higher than 
otherwise. However, only 22 of the 79 bidder returns examined here are M\&As of gaming targets. The next hypotheses consider the difference between gaming targets and nongaming targets.

\section{Testing Hypotheses: H3 \& H4 Testing Gaming Bidder CARs for Gaming Versus Nongaming Targets}

H3: Mean of bidder firms' CAR when target is gaming $\leq 0$

H4: Mean of bidder firms CAR when target is non-gaming $\leq 0$

To further investigate the phenomena of significantly positive bidder returns to gaming companies we further segregate our data into gaming firms acquiring gaming targets versus gaming firms acquiring nongaming targets. The impact of gaming regulation on bidder returns should be greatest when gaming companies acquire gaming targets.

Hypothesis $\mathrm{H} 3$ tests whether gaming bidder mean CARs when acquiring gaming targets are statistically positive. A total of 22 bidder CARs are available for this test. The average CAR for the 22 bidders $(\mathrm{N}=22)$ is $6.65 \%, \mathrm{t}(21)=2.060, \mathrm{SD}=15.1 \%, \mathrm{p}<.05$. However, because the sample size is small we also perform a one-sample Wilcoxon signed rank test. The results of the non-parametric test is significant at the $5 \%$ level $(\mathrm{p}=0.018)$. Thus, we reject the null hypothesis and our results support the alternative hypothesis that returns to bidders of gaming targets are significant and positive.

Hypothesis $\mathrm{H} 4$ tests whether gaming bidder mean CARS when acquiring nongaming targets are greater than zero. A total of 57 bidder CARS are available for this test. The average CAR for the 57 bidders $(\mathrm{N}=57)$ is $1.84 \%, \mathrm{t}(56)=1.922, \mathrm{SD}=7.21 \%, \mathrm{p}<.05$. The null hypothesis is rejected here as well, but the mean CAR for bidders of gaming targets $(6.65 \%)$ is much larger than for bidders of nongaming targets $(1.84 \%)$ and an independent sample T-test indicates the two mean CARs are significantly different from one another $(\mathrm{p}=.003)$. To further investigate the impact of gaming regulation on bidder returns we finally consider the bidder returns when gaming targets are public companies.

Table 4. Bidders Return by Target Industry Type

\begin{tabular}{cccccc}
\hline Hypotheses & Target industry & $\mathbf{N}$ & Mean (\%) & $\boldsymbol{t}$ statistic & $\boldsymbol{P}$ \\
\hline H2: $\mu=0$ & All targets & 79 & 3.18 & 2.772 & $0.007^{*}$ \\
H3: $\mu \leq 0$ & Gaming targets & 22 & 6.65 & 2.0604 & $0.026^{*}\left(0.0180^{*}\right)$ \\
H4: $\mu \leq 0$ & Nongaming targets & 57 & 1.84 & 1.922 & $0.030^{*}$ \\
H5: $\mu \leq 0$ & Public, gaming targets & 5 & 4.44 & 1.395 & $0.118^{*}\left(0.0215^{*}\right)$ \\
\hline
\end{tabular}

$* * p<.01$. * $p<.05$. ( $\mathrm{p}$ value for nonparametric, one-sample Wilcoxon Signed Rank test). Table 4 shows the $\mathrm{t}$ test results for the hypotheses 2 through 5. The cumulative abnormal return (CAR) is the average total return of the event (merger and acquisition) for the particular time period (-1 to 0 day of the event) across all firms.

\section{Testing Hypothesis: H5 Testing Gaming Bidder CARs for Public, Gaming Targets}

H5: Mean of bidder firms CAR when target is public and gaming $\leq 0$

Our review of the literature shows substantial evidence that bidder returns are significantly positive when targets are private but generally not significantly different from zero when targets 
are public. We believe the impact of gaming regulation on bidder returns is sufficiently strong to cause significant positive returns even when gaming targets are public companies. Hypothesis H5 tests whether gaming bidder mean CARs when acquiring public, gaming targets are greater than zero. Because the sample only includes $5 \mathrm{M} \& A s$ meeting this criteria a one-sample Wilcoxon signed rank test is performed. The results of the non-parametric test is significant at the 5\% level $(\mathrm{p}=0.0215)$. Thus, we reject the null hypothesis and our results support the alternative hypothesis that returns to bidders of public, gaming targets are significant and positive. Although we do not formally state a hypothesis, we also examined the returns to bidders of public, nongaming targets and the CARs were not significantly different from zero. The evidence supports the argument that bidder returns from M\&As of gaming targets are likely to be positive due to the reduced bidder competition caused by regulatory restrictions on ownership of gaming companies.

\section{Conclusions}

This study examines the cumulative abnormal returns (CARs) for gaming targets and bidding firms around the announcement of mergers and acquisitions (M\&As). The results showed that both targets and bidders had significant positive returns. The study finds that gaming targets enjoy significant positive returns. This is consistent with most of the literature showing that targets generally have significant positive returns (Bradley et al., 1988; Franks et al., 1991; Jensen \& Ruback, 1983; Lang, Stulz, \& Walking, 1989; Loughran \& Vijh, 1997; Sullivan, 1989).

Past research, as previously discussed, shows returns to bidders are mixed. The Kim's study (2001) finds that 2 -day returns of non-casino bidders are not significant $(\mu=1.22 \%)$, however those of casino hotels are significantly positive $(\mu=3.63 \%)$. Consistent with Kim's study, we find casino industry bidders do earn significant positive returns $(\mu=3.18 \%)$.

Previous studies found mixed results for bidder returns; some were positive, some were negative but many are close to zero. The positive bidder returns found here in the gaming industry is likely due to high entry barriers in the gaming industry reducing bidder competition and thus leading to higher returns for successful bidders. High entry barriers in gaming include the need to meet the qualifications for a gaming license, familiarity of gaming regulations, and industry experience. Thus, it can be difficult for a non-gaming bidder to acquire gaming targets which in turns causes less competition in gaming industry M\&As relative to other industries. However, a gaming bidder has already passed all these barriers. This probably contributes to higher returns for gaming bidders. Further evidence supporting this argument is the mean return to gaming bidders of gaming targets was significantly higher than the mean return to gaming bidders of nongaming targets. The reduced competition for gaming targets versus nongaming targets likely causes the higher returns for bidders of gaming targets. Additional evidence supporting this regulatory argument is the results showing that returns to gaming bidders of public, gaming targets are significantly positive. Evidence from the literature shows bidder returns from acquiring public targets are not significantly positive. The evidence here indicates the reduced competition for gaming targets is sufficiently strong to still create significant, positive returns for gaming bidders of public, gaming targets. 
What are the implications of this research for high level gaming executives who play a significant role in merger and acquisition decision-making? The lack of competition in bidding for acquisition targets in the gaming industry enhances the returns to well-thought out mergers and acquisitions. And investors in the gaming industry need not worry as much about possible value destroying mergers and acquisitions as they do in other industries.

Positive returns for both target and bidder firms as indicated by this study reveals there are likely synergistic gain from M\&As in the gaming industry. This is the first comprehensive merger and acquisition study in the gaming industry measuring M\&A success by considering stock price movements around the announcement date.

\section{Limitations and Future Studies}

This study focuses on the success of M\&As in the gaming industry using the dominant methodology employed for measuring the success of M\&As in the finance literature. Fruitful areas for further research along these lines would be a long term, post-acquisition performance study. This could provide further evidence of the success of M\&As in the gaming industry. Given that there is little empirical research on the success of M\&As in the gaming industry and the significant and different results found here, it would be very useful to confirm or refute the results by considering different sample periods or different methodologies. We considered M\&As in the gaming industry from 1985 to 2004. Therefore, future studies could examine this topic with more recent data.

There might be differences between private and public target returns. Our study has not considered private targets since the absence of market price information for private companies makes it very difficult to measure any gains or losses to private targets from acquisition.

\section{References}

Altunbas, Y., \& Marquez, D. (2008). Mergers and acquisitions and bank performance in Europe: The role of strategic similarities. Journal of Economics and Business, 60(3), 204-222.

Altunbas, Y., Gardener, E. P. M., Molyneux, P., \& Moore, B. (2001). Efficiency in European banking. European Economic Review, 45(10), 1931-1955.

Anderson, J. (1999). Making operational sense of mergers and acquisitions. The Electricity Journal, 12(7), 49-59.

Arık, E., \& Kutan, A. M. (2015). Do mergers and acquisitions create wealth effects? Evidence from twenty emerging markets. Eastern European Economics, 53(6), 529-550.

Beitel, P., Schiereck, D., \& Wahrenburg, M. (2004). Explaining M\&A success in European banks. European Financial Management, 10(1), 109-139.

Berger, A. N., Bonime, S. D., Goldberg, L. G., \& White, L. J. (2004). The dynamics of market entry: The effects of mergers and acquisitions on entry in the banking industry. The Journal of Business, 77(4), 797-834.

Besanko, D., D’Souza, J., \& Thiagarajan, S. R. (2001). The Effect of wholesale market deregulation on shareholder wealth in the electric power industry. Journal of Law and Economics, 44(1), 65-88.

Betton, S., Eckbo, B. E., \& Thorburn, K. S. (2008). Corporate takeovers: Handbook of corporate finance. Empirical Corporate Finance, 2, 291-430.

Bloom, B. A. N. (2010). Hotel company mergers from 2004 to 2007: Abnormal stock return and volume activity surrounding the merger announcement date. International Journal of Revenue Management, 4(3-4), 363-381.

Boyd Completes (2016). Boyd completes $\$ 380$ million acquisition of Aliante casino. Las Vegas Sun. Retrieved from https://lasvegassun.com/news/2016/sep/27/boyd-completes-acquisition-of-aliante-casino/

Bradley, M., Desai, A., \& Kim, E. H. (1988). Synergistic gains from corporate acquisitions and their division between the stockholders and target and acquiring firms. Journal of Financial Economics, 21(1), 3-40. 
Brown, S. J., \& Warner, J. B. (1985). Using daily stock returns: The case of event studies. Journal of Financial Economics, 14, 3-31.

Bruner, R. F. (2004). Applied mergers and acquisitions. Hoboken, NJ: John Wiley \& Sons.

Canina, L. (2001). Acquisitions in the lodging industry: Good news for buyers and sellers. Cornell Hotel \& Restaurant Administration Quarterly, 42(6), 47-54.

Canina, L., Kim, J. Y., \& Ma, Q. (2010). What we know about M\&A success: A research agenda for the lodging industry. Cornell Hospitality Quarterly, 51(1), 81-101.

Capron, L., \& Shen, J. C. (2007). Acquisitions of private vs. public firms: Private information, target selection, and acquirer returns. Strategic Management Journal, 28, 891-911.

Chang, S. (1998). Takeovers of privately held targets, methods of payment, and bidder returns. Journal of Finance, 53(2), 773-784.

Chatfield, H. K., Chatfield, R., \& Dalbor, M. (2012). Returns to hospitality acquisitions by method of payment. The Journal of Hospitality Financial Management, 20(1), 1-16.

Chatfield, H. K., Dalbor, M., \& Ramdeen, C. (2011). Returns of merger and acquisition activities in the restaurant industry. Journal of Foodservice Business Research, 14(3), 189-205.

Chew, D. H., \& Gillan, S. L. (Eds.). (2009). Global corporate governance. New York, NY: Columbia University Press.

Cybo-Ottone, A., \& Murgia, M. (2000). Mergers and shareholder wealth in European banking. Journal of Banking and Finance, 24(6), 831-859.

DeLong, G. L. (2001). Gains from focusing versus diversifying bank mergers. Journal of Financial Economics, $59(2), 221-252$.

Dogru, T. (2017). Under-vs over-investment: hotel firms' value around acquisitions. International Journal of Contemporary Hospitality Management, 29(8), 2050-2069.

Fecht, F., \& Grüner, H. P. (2008). Limits to International banking consolidation. Open Economics Review, 19(5), 651-666.

Focarelli, D., Panetta, F., \& Salleo, C. (2002). Why do banks merge? Journal of Money, Credit, and Banking, 34(4), 1047-1066.

Franks, J. R., Harris, R. S., \& Titman, S. (1991). The postmerger share-price performance of acquiring firms. Journal of Financial Economics, 29(1), 81-96.

Fuller, K., Netter, J., \& Stegemoller, M. (2002). What do returns to acquiring firms tell us? Evidence from firms that make many acquisitions. Journal of Finance, 57(4), 1763-1793.

Goergen, M., \& Renneboog, L. (2003). Value creation in large European mergers and acquisitions. Advances in Mergers and Acquisitions, 2, 96-146.

Halibozek, E. P., \& Kovacich, G. L. (2005). Mergers and acquisitions security: Corporate restructuring and security management. Waltham, MA: Butterworth-Heinemann.

Hansen, R. G., \& Lott, J. R. (1996). Externalities and corporate objectives in a world with diversified shareholder/consumers. Journal of Financial and Quantitative Analysis, 31(1), 43-68.

Houston, J. F., James, C. M., \& Ryngaert, M. D. (2001). Where do merger gains come from? Bank mergers from the perspective of insiders and outsiders. Journal of financial economics, 60(2-3), 285-331.

Hsu, L. T., \& Jang, S. (2007). The postmerger financial performance of hotel companies. Journal of Hospitality \& Tourism Research, 31(4), 471-485.

Jaber, M. W. (2004). The wealth effects of cross -border mergers and acquisitions: The case of the banking industry (Doctoral dissertation). Available from ProQuest Dissertations \& Theses Global (UMI No. 3133731)

Jensen, M., \& Ruback, R. (1983). The market for corporate control: The scientific evidence. Journal of Financial Economics, 11(1-4), 5-50.

Kim, S. H. (2001). An analysis of wealth effect to shareholders of the lodging industry in mergers and acquisitions (Unpublished doctoral dissertation). University of Nevada, Las Vegas, NE.

Kohers, N., \& Kohers, T. (2001). Takeovers by technology firms: Expectations vs. reality. Financial Management, $30(3), 35-54$.

Kwan, S., \& Eisenbeis, R. A. (1999). Mergers of publicly traded banking organizations revisited. Economic ReviewFederal Reserve Bank of Atlanta, 84(4), 26-37.

Lang, L., Stultz, R. M., \& Walkling, R. A. (1989). Managerial performance, Tobin's Q, and the gains from successful tender offers. Journal of Financial Economics, 24(1), 137-154.

Loughran, T., \& Vijh, A. (1997). Do long-term shareholders benefit from corporate acquisitions? Journal of Finance, 52(5), 1765-1790. 
Ma, Q., Zhang, W., \& Chowdhury, N. (2011). Stock performance of firms acquiring listed and unlisted lodging assets. Cornell Hospitality Quarterly, 52(3), 291-301.

Mitchell, M. L., \& Stafford, E. (2000). Managerial decisions and long-term stock price performance. Journal of Business, 73, 287-329.

Moeller, S. B., Schlingemann, F. P., \& Stulz, R. M. (2003). Do shareholders of acquiring firms gain from acquisitions? Retrieved from http://www.nber.org/papers/w9523

Moore, T. (2017). Golden Entertainment's purchase of four casinos illustrates midmarket consolidation. Las Vegas Sun. Retrieved from https://lasvegassun.com/news/2017/jun/13/golden-gamings-purchase-of-four-casinosillustrate/

Mukherjee, T. K., Kiymaz, H., \& Baker, H. K. (2004). Merger motives and target valuation: A survey of evidence from CFOs. Journal of Applied Finance, 14(2), 7-24.

Mulherin, J., \& Boone, A. (2000). Comparing acquisitions and divestitures. Journal of Corporate Finance, 6(2), 117-139.

Oak, S., \& Andrew, W. P. (2003). Information asymmetry around hospitality merger announcements. Journal of Hospitality Financial Management, 11(1), 13.

Oak, S., Andrew, W., \& Bryant, B. (2008). Explanations for the predominant use of cash financing in hospitality acquisitions. The Journal of Hospitality Financial Management, 16(1), 47-58.

Rhoades, S. A. (1992). Mergers and acquisitions in the U.S. banking industry: Evidence from the capital markets. Journal of Economic Literature, 30(2), 891-912.

Rhoades, S. A. (1998). The efficiency effects of bank mergers: An overview of case studies of nine mergers. Journal of Banking \& Finance, 22(3), 273-291.

Adams, R. M., Johnson, R. L., \& Pilloff, S. J. (2009). Market structure after horizontal mergers: Evidence from the banking industry. Review of Industrial Organization, 35(3), 217-231.

Rogers, A. D. (2005). Managerial risk-taking incentives and executive stock option Repricing: A study of US casino executives. Financial Management, 34, 95-121.

Schwert, G. W. (1996). Markup pricing in mergers and acquisitions. Journal of Financial Economics, 41(2), 153192.

Sheel, A., \& Nagpal, A. (2000). The post-merger equity value performance of acquiring firms in the hospitality industry. Journal of Hospitality Financial Management, 8(1), 37-45.

SPSS Base 10.0 Applications Guide, (1999). Chicago, IL: SPSS Inc.

Station Casinos Completes Palms deal. (2016). Las Vegas Sun. Retrieved from https://lasvegassun.com/news/2016/oct/04/station-casinos-completes-palms-deal/

Sullivan, M. J. (1989). Tax issues in mergers and acquisitions (Doctoral dissertation). Available from ProQuest Dissertations \& Theses Global (UMI No. 8916207)

Weston, J. F., Siu, J. A., \& Johnson, B. A. (2001). Takeovers, restructuring, and corporate governance. Upper Saddle River, NJ: Prentice Hall.

Yang, J., Qu, H., \& Kim, W. G. (2009). Merger abnormal returns and payment methods of hospitality firms. International Journal of Hospitality Management, 28, 579-585.

Yang. J., Kim, W. G., \& Qu, H. (2010). Post-merger stock performance of acquiring hospitality firms. Tourism Economics, 16(1), 185-195.

You, V. L., Caves, R. E., Henry, J. L., \& Smith, M. M. (1986). Mergers and bidders' wealth: Managerial and strategic factors. In Thomas III, L. G. (Eds.) The economics of strategic planning: essays in honor of Joel Dean (pp. 201-221). Lexington, MA: Lexington Books.

Zhang, H. (1995). Wealth effects of US bank takeovers. Applied Financial Economics, 5(5), 329-336. 